\title{
尺側皮静脈を用いた内シャントにおける累積開存率の検討
}

\author{
赤松 眞 春口洋昭唐仁原全中島一朗 \\ 渕之上 昌平 \\ 東京女子医科大学腎臓病総合医療センター第 3 外科
}

key words：ブラッドアクセス，尺側皮静脈，累積開存率

〈要旨〉

尺側皮静脈を用いた内シャントの累積開存率について，1994 年 4 月より 1998 年 10 月までの期間に作成した 45 例を対象とし，年齢，性別，透析歴などと累積開存率（primary patency）について検討を行った.

16 例が開存， 26 例が閉塞， 3 例はシャント流量が極めて不良なため新たなブラッドアクセスを作成した. 1 年, 3 年, および 5 年の累積開存率は光れどれ $51.1 \% ， 35.5 \% ， 25.4 \%$ あり, 橈側皮静脈を用いた内シャントと比較 して開存率は不良であった。 また統計学的有意差は認めなかったものの女性, 50 歳以上および透析導入後 1 年以上 の症例の累積開存率は低值であり，内シャント閉塞の危険因子と考えられた，閉塞症例では，シャント作成後 1 か 月以内に 10 例 (34.5\%)，2 6 6月間に 7 例 $(24.1 \%) ， 7 \sim 12$ か月間に 5 例 $(17.3 \%)$ と 1 年以内に $75.9 \%$ の症例 が閉塞していた。この結果から，使用した尺側皮静脈はもともと内シャントに適していなかった可能性があると推 察され，尺側内シャントを作成する時点ですでに閉塞する可能性が高いと予想できていた症例も含まれると考えら れた.

尺側皮静脈を用いた内シャントの累積開存率は決して良好とはいえなかった。しかし今後も成績が不良であるこ とを十分理解した上で, 人工血管移植やカテーテル留置を選択する前にアクセスの一選択肢として尺側内シャント を考虑すべきであると考える.

\section{Analysis of cumulative primary patency of ulnobasilic fistula for hemodialysis}

Makoto Akamatsu, Hiroaki Haruguchi, Tamotsu Tojinbara, Ichiro Nakajima, Shohei Fuchinoue Department of Surgery III, Tokyo Women's Medical University

Between April 1994 and October 1998, 45 ulnobasilic arteriovenous fistula were constructed using the ulnar artery and basilic vein in the distal forearm for the permanent hemodialysis access. We analyzed the influence of age, gender and hemodiablysis duration on the cumulative primary patency in these patients. Their mean age was $60.2 \pm 12.8$ years (range: $28 \sim 81$ years) and median follow-up was $37.7 \pm 17.1$ months (range : 12 68 months). Sixteen fistulas were patent, twenty-six fistulas were occluded and three fistulas had not matured adequately for hemodialysis access. The cumulative primary patency rate was $51.1 \%$ at one year, $35.5 \%$ at three years, and $25.4 \%$ at five years. The primary patency of ulnobasilic arteriovenous fistula was worse compared with that of the radiocephalic fistula, or graft implantation. The cumulative primary patency rates was slightly lower in female patients, patients 50 or more years old and the patients who had undergone hemodialysis for more than one year. Ten fistulas (35.4\%) occluded within the first month and twenty-two fistulas (75.9\%) occluded within the first year. It was suggested that in some patients whose fistulas occluded earlier, the basilic vein wasn't adequate for arteriovenous fistula.

In conclusion, although the cumulative patency rate of ulnobasilic arteriovenous fistula was insufficient, we should consider an alternative route in patients with vascular access complications.

赤松 真 現 板橋中央総合病院血液浄化療法センター T174-0051 東京都板橋区小豆沢2-12-7 (03-3967-1181)

Makoto Akamatsu Fax 03-3967-1641

〔受付：平成 12 年 4 月 6 日, 受理：平成 13 年 1 月 18 日〕 


\section{緒 言}

ブラッドアクセス（以下アクセスと略す）は前腕の 橈側皮静脈と橈骨動脈とを吻合する内シャント (radiocephalic fistula, 以下橈側内シャントと略す) が 代表的である1)。その主な理由は手術が比較的容易で, また橈側皮静脈は血管径が太く直線的に走行するなど その後の穿刺にとって好条件がそろっているためと考 えられる。これに対して尺側皮静脈を用いた内シャン 卜 (ulnobasilic fistula, 以下尺側内シャントと略す) は尺側皮静脈の血管径がやや細く手背側を蛇行し，ま た尺骨動脈も細いなど不都合な点が少なくない。その ため橈側内シャントに比較するとあまり実施されてい ないのが現状である。一方, 維持透析の長期化に伴う 新たな合併症が問題となっており，そのひとつにアク セストラブルがあげられる，橈側皮静脈を使用できな い場合，尺側内シャント，動脈の表在化，人工血管移 植,さらにはカテーテル留置2,3どの方法が考えられ るが，可能な限り自己静脈を利用するという観点から 尺側皮静脈を用いた内シャント作成を選択する場合が ある，そこで我々の施設における尺側内シャントの成 績について検討した。

\section{I．対象および方法}

1994 年 4 月より 1998 年 10 月までの期間に我々の 施設で作成した尺側内シャント症例のうち，追跡調查 可能であった 48 例中死亡した 3 例を除いた 45 例を対 象とした。手術は 10 年以上の経験を有し，年間 50 例 以上の症例数を担当する医師が執刀し，尺骨動脈と尺 側皮静脈を側々吻合したのち静脈末梢側を結禁する手 技（機能的端側吻合）で作成した。吻合に使用した尺 側皮静脈径は 3〜 $6 \mathrm{~mm}$ （平均 $3.8 \pm 0.8 \mathrm{mm）であり，}$
また経皮的血管拡張術を施行した症例は認めなかっ た。累積開存率 (primary patency) は尺側内シャント 作成日より 1999 年 10 月までの開存期間をもとに Kaplan-Meier 法を用いて算定した。 なお累積開存率を算 定するにあたり，血流不良症例については新たなブ ラッドアクセスを作成した時点を閉塞日として閉塞例 に含めた。また primary patency に与える要因を検討 するため年齢，性別および透析歴別による累積開存率 を算定した，累積開存率の各群間における有意差検定 は Logrank test を，その他はカイ二乗検定または $t$ 検 定を用いた。すべての検定において $\mathrm{p}<0.05$ をもって 有意とした。

\section{II. 結 果}

45 症例の性別および年齢は, 男性 25 例, 女性 20 例, 28 歳から 81 歳で平均 $60.2 \pm 12.8$ 歳であった. 1999 年 10 月の時点で 16 例が開存しており, 残りの 29 例のう ち 26 例は閉塞, 3 例はシャント流量が極めて不良なた め新たなブラッドアクセスを作成した。観察期間は 12 か月から 68 か月，平均 $37.7 \pm 17.1$ か月であった．図 1 に全症例の 5 年累積開存率を示す. 1 年, 2 年, 3 年, 4 年および 5 年開存率はそれぞれ $51.1 \% ， 40.0 \%$, $35.5 \% ， 25.4 \% ， 25.4 \%$ あった。図 2 は男女別の累 積開存率である。男性/女性の 1 年, 3 年累積開存率は それぞれ 52.0/50.0\%，47.3/20.8\%で女性の開存率は 男性と比較してやや低值であったが両群間に有意差は 認めなかった $(p=0.266)$. 図 3 に年齢と累積開存率と の関係を示す. 50 歳未満/ 50 歳以上の 1 年, 3 年累積開 存率はそれぞれ $61.5 / 46.9 \% ， 52.7 / 27.8 \%$ で 50 歳以 上の累積開存率はやや低值であったが両群間に有意差 は認めなかった $(\mathrm{p}=0.249)$. 図 4 に透析歴と累積開存 率との関係を示す. 透析導入後 1 年未満, 1 年以上 3 年 未満および 3 年以上の 3 群に分け比較検討した。 1 年,

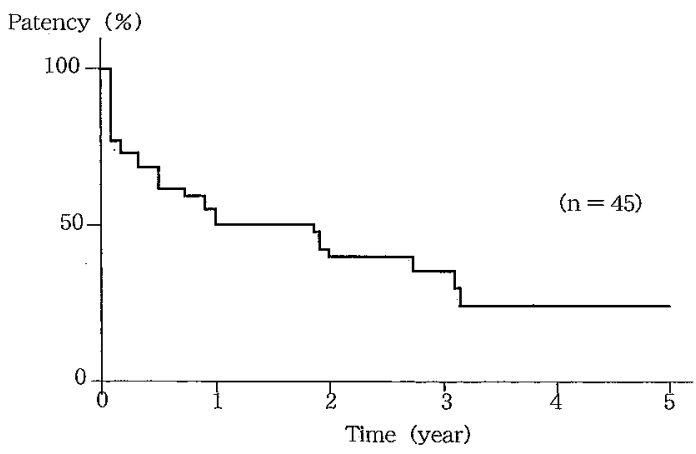

図 1 Cumulative primary patency of ulnobasilic fistulas.

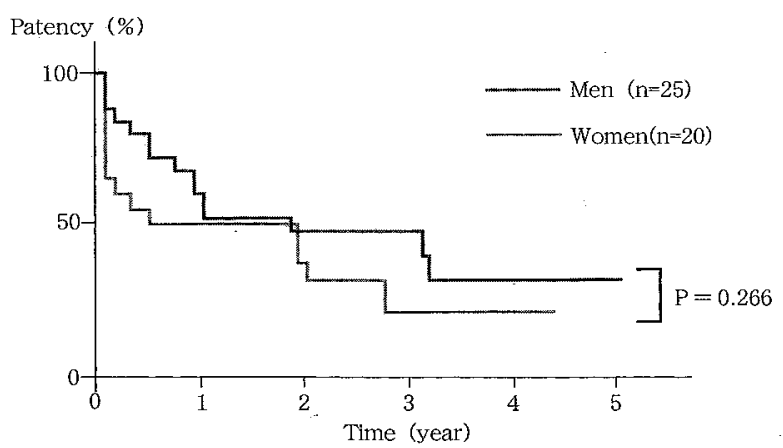

図 2 Influence of sex on the cumulative primary patency of ulnobasilic fistuläs. 


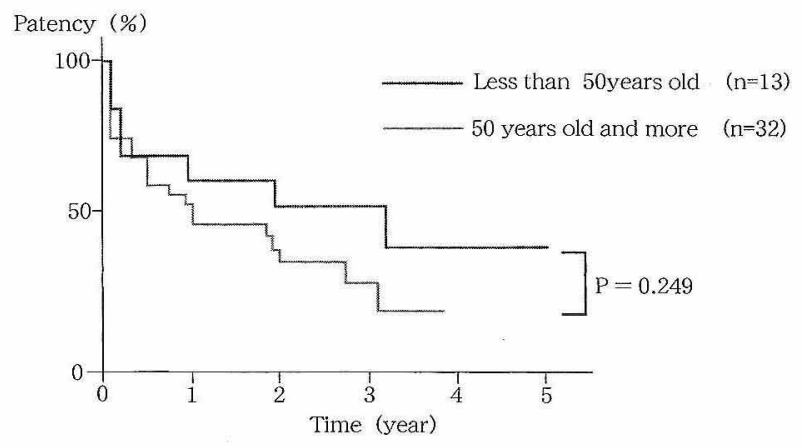

図 3 Influence of age on the cumulative primary patency of ulnobasilic fistulas.

Occulusion time

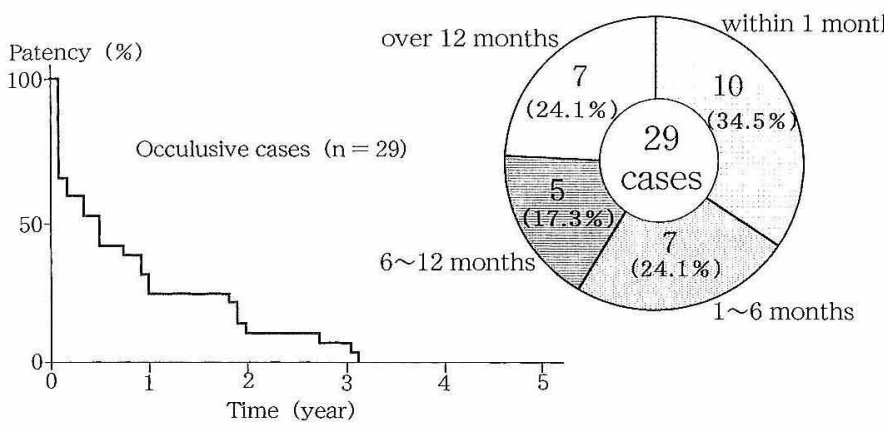

図 5 Cumulative patency of occulusive cases and occulusion time.

3 年累積開存率はそれぞれ 70.0/40.0/48.0\%，46.7/ $26.7 / 35.6 \%$ で, 導入後 1 年未満の累積開存率は他の 2 群に比較してやや良好であったが有意差は認めなかっ た $(\mathrm{p}=0.273 / 0.371)$.

閉塞例についてみると，シャント閉塞までの期間は 最短で 2 日, 最長で 38 か月, 平均 $10.2 \pm 2.2$ か月であ り，シャント作成後 1 か月以内に 10 例 (34.5\%)，2〜6 か月間に 7 例 (24.1\%)，7１2 朋月間に 5 例 (17.3\%) が閉塞しており，1 年以内に $75.9 \%$ 症例が閉塞した (図 5)。また再建術式は中枢側の尺側皮静脈を用いた 内シャント再建 5 例 $(17.2 \%)$ ， パッチグラフトによる 中枢側狭窄部解除 1 例 $(3.5 \%)$, 上腕動脈表在化 3 例 (10.3\%), 対側の橈側内シャント形成 5 例 $(17.2 \%)$, 肘部での内シャント形成 1 例 $(3.5 \%)$ ，人工血管移植 14 例（48.3\%）であった（表）。

\section{III. 考 察}

透析患者のアクセスには内シャント, 動脈表在化, 人工血管移植，カテーテル留置など種々の方法が存在 するが，通常は前腕の自己静脈と動脈を吻合する内 シャント形成術が一般的である，前腕の主な皮静脈は 橈側皮静脈と尺側皮静脈であり, 橈側皮静脈は静脈径

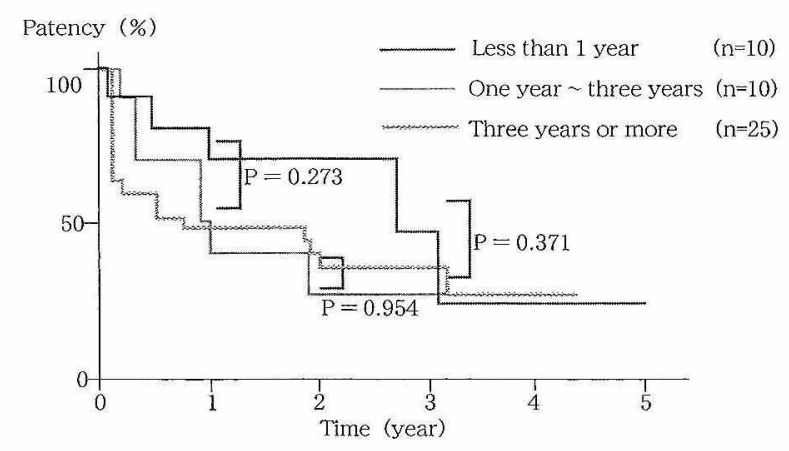

図 4 Influence of hemodialysis duration on the cumulative primary patency of ulnobasilic fistulas.

表 Surgical procedure in occlusive patients.

\begin{tabular}{lcc}
\hline \multicolumn{1}{c}{ Surgical procedure } & Cases & (\%) \\
\hline ulnovasilic fistula at proximal site & 5 & $(17.2)$ \\
reconstruction of stenosis & 1 & $(3.5)$ \\
superficialization of brachial artery & 3 & $(10.3)$ \\
radiocephalic fistura at opposite forearm & 5 & $(17.2)$ \\
arteriovenous fistula at elbow & 1 & $(3.5)$ \\
arteriovenous graft inplantation & 14 & $(48.3)$ \\
\hline
\end{tabular}

が太く手掌側をほほほ直線的に走行し，長い範囲にわ たって穿刺が可能であるという特徴がある。これに対 して尺側皮静脈は静脈径が細く手背側を蛇行して走行 するなど穿刺が難しい場合も少なくない，そのため橈 側皮静脈を選択することが多いと思われるが，たび重 なるアクセストラブルにより橈側皮静脈が使用できな くなった場合，尺側皮静脈を用いることとなる。この 際尺側内シャントの開存率は橈側内シャントに比べて 悪いのではないか，といった漠然とした印象を否定し えない，そこで今回我々の施設で作成した尺側内シャ ントについて累積開存率を中心に検討を行った。

Ravichandran ら ${ }^{4)}$ にると，尺側内シャントを作成 した 19 例のうち 11 例が開存し，開存期間は最長で 39 か月であったとしている. 文献上では尺側内シャント の累積開存率に関する報告はみられなかったため, 橈 側内シャントの成績と比較することとし，また自験例 は調査中のため諸家の報告を参照した。それによると 橈側内シャントの累積開存率は, 1 年で 70 $80 \%, 3$ 年

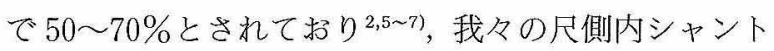
の成績（1 年で $55.1 \% ， 3$ 年で $35.5 \%$ ） は良好とはい えなかった。

内シャントの開存性に関与する危険因子として年 齢, 性別お よび糖尿病の有無などがあげられてい $~^{3,7,8)}$. 今回糖尿病に関しては症例数が少ないため検 討しなかったが，透析歷についても検討した。その結 果 50 歳以上, 女性, および透析導入後 1 年以上の症例 
では累積開存率が不良であった，ただしいづれも統計 学的有意差は認めなかった. 橈側内シャントでは高齢, 女性および糖尿病患者における累積開存率が低いとさ れており ${ }^{3,7,8)}$, 症例数が少なく検討を行えなかった糖 尿病を除けば，尺側内シャントにおいても同様の傾向 であった。.また閉塞例の $75.4 \%$ 症例は 1 年以内に閉 塞し, 特に $34.5 \%$ の症例は術後 1 加月以内と極めて早 い段階で閉塞していた。さらにその後のアクセス再建 方法として中枢側の尺側皮静脈を使用した症例は再吻 合術 5 例抒よび狭窄部形成術 1 例の計 6 例 (20.7\%) のみで, 残りの症例は人工血管移植術, 対側の橈側内 シャント形成術, 上腕動脈表在化術などとなっていた。 したがって使用した尺側皮静脈の中にはもともと内 シャントとして適して扔らず，内シャントを作成する 時点で早期の閉塞が危惧される症例も含まれると考光 られた。さらに尺側内シャント作成以前のシャントト ラブルの回数，尺骨動脈の状態あるいは尺側内シャン 卜作成後の穿刺ミスの頻度なども累積開存率に影響を 与元ることが予想され，今後検討が必要であると思わ れた。

近年, 長期の血液透析に伴いアクセストラブルが多 くなっている，その結果自己静脈でのアクセス形成が 困難な症例が増加し，人工血管を使用する頻度が増え ている.このことについて Schwab) は Nephrology Forum のなかで米国における全アクセス症例の 70\% が人工血管 (PTFE)を使用するに至っていると述べて おり，さらに導入期より人工血管によるアクセスを作 成する症例も漸増しているとしている。この理由とし て, 透析の長期化に加光内シャント作成時期の遅れに 伴う自己静脈の破綻，糖尿病患者扝よび高齢者の増加 などを要因としてあげている。また Bonucchi ら9は 1985 年当時は前腕佉内シャントを形成する症例が中 心であったが，1995 年には前腕の内シャントば減少 し, 肘部で作成する症例や長期留置型カテーテルを使 用する症例が増加していると報告している．さらに Feldman ら ${ }^{10,11)}$ は入院治療を要した透析患者の $25 \%$ はアクセストラブルが原因で，これにかかる医療費は 透析患者総入院費用の $50 \%$ を占めるとしており, 頻回 なアクセストラブルは患者に対する負担のみでなく医 療費の增加にもつながるとしている，そのような観点 办らは開存性の低い術式は選択されにくく, 初回上り 肘部や上腕での内シャント形成術, 人工血管移植術が 増加していることも理解できる，また人工血管移植術 の累積開存率も徐々に向上し secondary patency と して 2 年で $80 \%$ 程度との報告 ${ }^{12)}$ ある。 しかし，いか なる方法も万能でない状況からは, 1 年でも長く自己
静脈を用いたアクセスを使用し，人工血管移植やカ テーテルアクセスは次のオプションとして確保してお く方が妥当ではないかと考える.

\section{結 。語}

尺側皮静脈を用いた内シャントの累積開存率は 1 年 で $51.1 \%, 5$ 年で $25.4 \%$ と決して良好とはいえなかっ た。しかし今後も成績が不良であることを十分理解し た上で，人工血管移植やカテーテル留置を選択する前 に, アクセスの一選択肢として尺側内シャントを考慮 すべきであると考光る。

\section{文献}

1) Brescia MJ, Cimino JE, Appel K, Hurwich BJ : Chronic hemodialysis using venipuncuture and a surgically created arteriovenous fistula. N Engl J Med 275 : 1089-1092, 1966

2) Schwab SJ : Vascular access for hemodialysis. Kidney Int $55:$ 2078-2090, 1999

3) Masaki T, Yorioka N, Kyuden Y, Yamashita K, Taniguchi Y, Yamakido M, Tanaka J, Harada S : Factors influencing arteriovenus fistula dysfunction in Japanese patients on chronic hemodialysis. Int J Artif Organs $22: 14-17,1999$

4) Ravichandran R, Rao SM, Bokade CM, Abraham $\mathrm{V}$ : Ulunobasilic arteriovenous fistulae for hemodialysis. Dialysis Transplantat 28 : 314-316, 1999

5) Moray G, Karakayali H, Yildirim S, Demirag A, Bilgin $N$ : Fifteen years of experience in vascular access surgery. Transplant Proc 30:764-766, 1998

6）藤田英志, 矢野善己, 尾崎 直, 山崎一也, 石井正徳： 血液透析用内シャント手術成績および影響を与える危 険因子. 日血外会誌 6：719-722，1997

7) Golledge J, Smith CJ, Emery J, Farrington $\mathrm{K}$, Thompson $\mathrm{HH}$ : Outcome of primary radiocephalic fistula for haemodialysis. Br J Surg 86 : 211-216, 1999

8) Lin S-L, Huang C-H, Chen H-S, Hsu W-A, Yen C$\mathrm{J}$, Yen T-S: Effects of age and diabetes on blood flow rate and primary outcome of newly created hemodialysis arteriovenous fistulas. Am J Nephrol 18:96-100, 1998

9) Bonucchi D, D'Amelio A, Grosoli M, Baraldi A, Cappelli G: Vascular access for haemodialysis: from surgical procedure to an integrated therapeutic approach. Nephrol Dial Transplant $13: 78-81$, 1998

10) Feldman HI, Kobrin S, Wasserstein A : Hemodialysis vascular access morbidity. (editional review) J Am Soc Nephrol 7 : 523-535, 1993 
11) Feldman HI, Held PJ, Hutchinson JT, Stoiber E, Hartigan MF, Berlin JA : Hemodialysis vascular access morbidity in the United States. Kidney Int $43:$ 1091-1096, 1993

12) Hurlbert SN, Mattos MA, Henretta JP, Ramsey DE, Barlmeier LD, Hodgson KJ, Sumner DS : Long- term patency rates, complications and cost-effectiveness of polytetrafluoroethylene (PTFE) grafts for hemodialysis access : a prospective study that compares Impra Versus Gore-tex grafts. Cardiovasc Surg 6 :652-656, 1998 